У,

ББК 67.405.1

DOI 10.22394/1682-2358-2019-2-95-100

A.A. Ivanov, Candidate of Sciences, senior lecturer of the Labor Law Department of the Saratov State Academy of Law

\section{TEACHERS' ACTIVITY IN SOCIAL NETWORKS: LEGAL ISSUES}

The issues related to the activities of teachers in social networks from the viewpoint of labor law norms and the legislation on education are studied. The proposal is made to supplement Chapter 52 of the Labor Code of the Russian Federation with a definition of immoral misconduct as applied to teaching staff in the context of social networks.

Key words and word-combinations: social networks, the status of an educator, immoral offense.
А.А. ИВанов, кандидат юридиеских наук, стариий преподаВатель кафедрь трудового праља Саратовской государственной юридической академии (email: artiom-depeche@yandex.ru)

\section{АКТИВНОСТЬ ПЕААГОГИЧЕСКИХ РАБОТНИКОВ В СОЦИААЬНЫХ СЕТЯХ:
ПРАВОВЫЕ ВОПРОСЫ}

Аннотация. Исследуются вопросы, связанные с действиями педагогов в социальных сетях с точки зрения норм трудового права и законодательства об образовании. Обосновывается предложение дополнить главу 52 Трудового кодекса Российской Федерации дефиницией аморального проступка применительно к педагогическим работникам в контексте деятельности в социальных сетях.

Ключевые слова и словосочетания: социальные сети, аккаунт, статус педагогического работника, аморальный проступок.

Cost џиальные сети с самого момента своего появления в начале нулевых годов стали неотъемлемой частью жизни современного человека. Не будет ошибкой утверждать, что многие представители размичных возрастных категорий пользуются социамьными сетями в самых разных цемях, в основном Аля того, чтобы Аелиться с Арузьями фотографиями, историями из жизни, аудиовизуамьными файлами, Амя продажи какого-мибо товара ими предложения услуг. 
Пожалуй, самыми распространенными действиями в социальных сетях явмяются загрузка и размешение фотографий и видеозаписей, связанных с событиями, происходящих в жизни пользователей. ОАнако порой цюди размещают на своих страницах материалы (фото, видео, посты) сомнительного содержания, которые вызывают не только неловкость, но и заинтересованность соответствующих органов исполнительной власти. Такая категория материалов не входит в предмет данного научного исследования, сосредоточим внимание на публикации тех материалов, которые не попадают в орбиту уголовных и уголовно-процессуальных отношений.

Чаше всего граждане публикуют фотографии с мест метнего отпуска, во время празднования каких-цибо событий, иногАа они могут быть преАставлены в несвойственном, по мнению их целевой аудитории, виде. Особенно это касается преАставитемей такой специфической профессиональной группы, как педагоги. Известно немало скандальных случаев, связанных с неоднозначностью подобных ситуаций. Например, учитель на своей страниџе в соџиальной сети «ВКонтакте» выложиц фотографии с праздника, где был запечатлен с алкогольными напитками. В результате поступили обращения к руководителю образовательного учреждения с предложениями по принятию определенных мер воздействия на своих сотрудников [1]. При этом возникает вопрос о моральном облике поднимающих такие проблемы родителей, среди которых немало маргинальных эмементов, занимающихся не столько воспитанием своих детей, сколько мониторингом аккаунтов учителей [2] .

Таким образом, следует решить вопросы, межащие в пмоскости правового отраслевого регулирования:

1) правомерно ми педагогическому работнику публиковать материалы, связанные с их мичной жизнью; в данном случае, конечно, исключаются фотографии әротического характера или посты, связанные с экстремизмом;

2) правомерны ки требования руководителя образовательной организаџии об удалении учителем своих страниџ из соџиальных сетей;

3) насколько правомерно увольнение сотрудника за активность в соџиальных сетях;

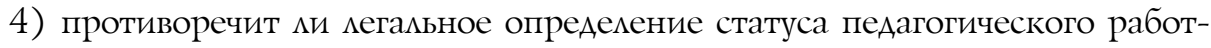
ника, предусмотренное в Федеральном законе «Об образовании в Российской Федерации» [3], конституционным нормам [4] ;

5) что следует считать аморальным проступком применительно к данным отношениям.

Аостаточно дискуссионен вопрос о правомерности требований руководителя образовательной организации об удалении педагогическими работниками своих страниџ из соџиальных сетей. Исследователи отмечают, что в процессе трудоустройства некоторые работодатели требуют, кроме документов, необходимых для приема на работу, ссылки на профили в соџиальных сетях. По данным статистики, в которую входят и педагогические работники, в $47 \%$ ситуаџий переА приемом на работу страниџы соискателей просматриваются; $16 \%$ работодателей регулярно отслеживают активность своих сотрудников; $4 \%$ увольнений межкит в плоскости активности в социальных сетях [5]. Воз- 
никают ситуации, когда руководители образовательных организаций требуют от педагогов удамения страниџ из соџиальных сетей [6]. В подобных ситуаџиях закон был и остается на стороне сотрудников. Так, исходя из смысла ст. 22 Трудового кодекса РФ, применительно к активности педагогов в сетях, при отсутствии фактов, свидетельствующих об аморальном поведении, что может быть основанием к увольнению педагога (и только исходя из результатов служебного расследования), директор не имеет права требовать миквидации страниц своих сотрудников, а Аишь попросить об этом работников [7] . ПеАагоги вправе по своему усмотрению удовцетворить или нет эту просьбу.

Аеятельность (в рамках закона) в социальных сетях педагогов, а равно и Аюбого Аругого гражданина, является неотъемлемым конституџионным правом мичности. Требования администрации образовательной организации, оформленные в письменном или устном виде, об удалении аккаунтов являются незаконными. Более того, страница в соџиальной сети - это эмемент частной жизни. Если же имеется общение с учениками в электронной форме, руководитель образовательной организаџии может требовать цишь соблюдения правиц переписки в соџиальных сетях.

Вопрос об увольнении педагогического работника в контексте его активности в социальных сетях подмежит специальному юридическому урегулированию. В ст. 81 Трудового кодекса РФ содержится юридическая норма, предусматриваюшая основания дмя прекрашения трудовых отношений по инициативе работодателя, - неоднократное неисполнение работником своих обязанностей без уважительных причин при наличии дисциплинарного взыскания. Применительно к трудовым отношениям считаем необходимым установить причинно-следственную связь межку активностью в социальных сетях и нарушением трудовой дисциплины. Так, заслуживает внимания случай, когда психолог Центра соџиальной защиты населения г. Москвы была уволена за видеосъемку на рабочем месте. Увольнение было связано со вступмением в действие приказа от 9 декабря 2009 г. № 1499 «О принятии дополнительных мер по предотвращению террористических актов в учреждениях социальной защиты населения города Москвь» [8] Аепартамента соџиальной защиты населения г. Москвы. В соответствии с приказом фото- и видеосъемка разрешалась только после соответствуюшего согласования с Аепартаментом. Сотрудниџа, вопреки приказу, неоднократно осуществляла съемку на рабочем месте, а отснятый материал выкладывала в социальную сеть. В результате женшина была уволена по основаниям, предусмотренным п. 5 ст. 81 ТК РФ, за неоднократное неисполнение трудовых обязанностей. Важным моментом здесь является факт того, в свободное или рабочее время сотрудник находияся в соџиальных сетях. Если работник проявцял изАишнюю активность в соџиальных сетях в свободное от исполнения трудовых обязанностей время, то вполне могут быть обоснованными претензии работодателя при наличии причинно-смедственной связи межАу действиями в сети, которые наносят ущерб репутаџии организации.

При изучении вопроса о правомерности расторжения трудового договора с педагогическими работниками следует сделать акцент на нравственном 
аспекте. Исходя из смысла ч. 1 п. 8 ст. 81 ТК РФ можно отметить, что основанием дмя увольнения сотрудника выполняющего воспитатемьные функции, явмяется совершение им аморального проступка. Естественно, не оправдываются мица, размешающие в сетях откровенные фото или экстремистские материалы [9].

Например, заслуживает внимания определение от 11 мая 2016 г. Жецезнодорожного районного суда г. Екатеринбурга по делу № 2-2475/2016. Учитель русского языка и китературы А.А. Реутт обратился в суа с иском к муниципальному бюджетному общеобразовательному учреждению средней общеобразовательной школе № 119 о признании приказа об увольнении незаконным, восстановлении на работе, взыскании заработка за время вынужденного прогула, взыскании компенсации морального вреда. В ходе рассмотрения дела судом было установлено, что имелась серия аморальных проступков со стороны истца, который допускал на занятиях оскорбительные высказывания в аАрес учеников; использовал ненормативную мексику в проџессе проведения занятий; на страниџе в соџиальной сети «ВКонтакте», открытой дмя учащихся, публиковац изображения, определенные специалистами как запрещенные к пропаганде и носящие аморальный характер [10].

Еще один случай касается учителя истории из Уфы, которая после метнего отдыха в Турции поделикась своим негативным мнением о поведении русских туристов. Запись на ее страниџе была следующего содержания: «Русское бабье, как вас научилась ненавидеть, отдыхая в Турции. Как можно загадить все вокруг и испортить своим поведением менталитет турков-мужчин?» [11]. После разгоревшегося скандала учительниџа вынуждена была уволиться. Вместе с тем можно привести множество данных, свидетельствующих о низком культурном уровне поведения наших сограждан на иностранных курортах [12]. Такого резонанса не произошло бы, если бы автором сетевых публикаций стала «непубцичная» мичность, например, преАставитель рабочей специальности.

Исследователи выявили перечень конкретных действий, которые не следует делать педагогам на своих страниџах в соџиальных сетях: публиковать посты и выкладывать фотографии в рабочее время; размещать провокаџионные записи об участии в скандалах, драках; выставлять конфиденциальную информацию о детях, родителях и комлегах; проводить политическую агитаџию и делать ремигиозные призывы; распространять кмевету и разглашать тайну усыновления; публиковать фотографии в одежде с эмементами эротики и декать уничижительные высказывания о работе [13] .

При решении вопроса о том, правомерно ки уволить сотрудника из-за активных действий в сощиальных сетях, следует учитывать следующие моменты: в какое время (рабочее или свободное от работы) сотрудник действовал в сети; в чем проявляется причинно-следственная связь межАу активностью в сетях и его трудовых обязанностями, исходя из которых правоприменитель АОАжен правицьно решить трудовой спор.

Заслуживает внимания случай, произошедший весной 2016 г., когАа в ПоАмосковье родители добились увольнения 26-летней учительниџы ИЗО. Аевуш- 
ка выкладывала на своей страниџе фотографии, где была запечатлена в откровенных нарядах. Хотя она настаивала на том, что данные снимки не явмяются эротическими, ей пришлось уволиться [2] .

В подобных ситуациях возникает и встречный вопрос, связанный с родителями и иными законными представителями интересов ребенка, осуществмяющими в соответствии с прямым указанием законодателя воспитательные функции. Имеются случаи, когда эти миџа ведут аморальный образ жизни, позволяют себе девиантное поведение, фиксируя его на фотографиях и в прямых транслящиях в соџиальных сетях [14] . Но в отличие от пеАагогов - пубмичных Аюдей, это не вызывает обшественного резонанса.

Как отмечалось, российское трудовое законодательство содержит понятие аморального проступка, применение которого относится в первую очередь к педагогам как работникам, осуществмяющим воспитательные функщии. Онако, кроме учителей, участниками образовательных отношений являются и родители учащихся, на которых законодательством возложены обязанности по воспитанию своих детей. Но родитель сам может входить в «группу риска» и быть маргинальным элементом, что сегодня не редкость и не вызывает обшественного резонанса.

Применительно к образовательным отношениям, которые тесно переплетаются с трудовыми, цемесообразно рекомендовать расширение сферы действия правовой категории аморального проступка и включить в круг его действия законных представитемей учащихся: родителей и иных физических киц, что, по нашему мнению, позволит установить баланс между родителями и педагогами в контексте действий в соџиальных сетях. Реализаџия данной рекомендации в сфере школьного образования позволит классным руководитемям, имея соответствующую информацию из социальных сетей о маргинализированных родителях, применять к ним аналогичные меры с привлечением соответствующих органов исполнительной власти.

Исходя из проведенного исследования, представляется необходимым дополнить главу 52 ТК РФ мегальной дефиницией аморамьного проступка применительно к педагогическим работникам, использующим соџиальные сети. Под таковым следует понимать действия педагогических работников, связанные с опубликованием в социальных сетях материалов, содержащих элементы порнографии, педофилии, издевательства над животными и иные противоправные деяния, в том числе связанные с поощрением наркомании, алкоголизма, экстремизма, разжиганием межнаџиональной и религиозной ненависти. По нашему мнению, такая формулировка может в будущем уравнять баланс между педагогами и родитемями в проџессе образовательных отношений и межАу педагогами и администрацией в контексте соџиальных сетей. Полагаем, что предусмотренные случаи по своей сущности наносят ушерб нравственности и развитию кичности целевой аудитории - учащимся. В перспективе указанная формулировка сможет защитить педагогических работников, использующих социальные сети, от необоснованных нападок со стороны «бдительных» родителей и спорных решений как администрации образовательной организаџии, так и судебных инстанџий. 
Очевидно, что социальные сети в условиях развития информаџионного общества могут быть не компрометирующим инструментом (как учитемей, так и родителей), а пмощадкой Аля развития учащихся. Соџиальные сети могут стать верным помощником учителя. Общение с учениками в сети представляет собой дополнительный инструмент образования и воспитания. К примеру, учитель истории и обществознания из Новосибирска Е. Вервейн, чтобы заинтересовать учащихся в предмете, использует Instagram, где проводит викторины [15]. Профессиональный стандарт и темпы меняющейся окружающей действительности диктуют новые требования к формированию специациста, способного к работе с информационными технологиями в процессе решения профессиональных задач. При правицьно выстроенном диалоге межАу педагогом и учащимися соџиальные сети служат среАством формирования информационных и коммуникаџионных компетенций $[16 ; 17]$.

\section{Библиографический список}

1. Учителя тоже люди: российские учительницы устроили флешмоб и выложили фото в купальниках в поддержку уволенной коллеги. URL: http://www. rep.ru

2. Двойная жизнь учителей: зачем родители следят за их социальными сетями. URL: http:// news.rambler.ru

3. Об образовании в Российской Федерации: Федер. закон от 29 дек. 2012 г. № 273-Ф3 (в ред. от 25 дек. 2018 г. № 497-Ф3) // СЗ РФ. 2012. № 53, ч. 1. Ст. 7598.

4. Конституция Российской Федерации // СЗ РФ. 2014. № 31. Ст. 4398.

5. Учительницу уволили за фото: как социальные сети отражаются на работе. URL: http:// www.psychologist.tips.

6. Может ли директор школы запретить учителям общаться с учащимися в социальных сетях? URL: http://www.pravoved.ru/question/1788121.

7. Трудовой кодекс Российской Федерации от 30 дек. 2001 г. № 197-Ф3 (с изм. от 27 дек. 2018 г. № 315-Ф3) // С3 РФ. 2002. № 1, ч. І. Ст. 3.

8. Апелляционное определение Московского городского суда от 28 мая 2012 г. № 33-12252. URL: http://garant.ru

9. Решение Октябрьского районного суда г. Новосибирска по делу № 2-2032/2015. URL: http://www.sudact.ru

10. Определение по делу № 2-2475/2016 Железнодорожного районного суда города Екатеринбурга (Свердловская область). URL: http://www. sudact.ru

11. В Уфе учительницу требуют уволить из-за сообщения в Фейсбуке. URL: http://www. ufa.kp.ru

12. Почему русских туристов не любят за границей? URL: http://www.posprikaz.ru

13. Вавилова A. Чего не стоит делать в социальных сетях педагогам // Справочник педагога-психолога. Школа. 2018. № 7. С. 34-39.

14. Ещенко C.M. Аморальная семья и ее влияние на поведение ребенка // Novainfo. 2017. № 64-2. URL:http://novainfo.ru/article/12870.

15. Учитель и соцсети: правила выживания. URL: http://pedsovet.org.

16. Еремина O.Е. Использование веб-квестов в профессиональном образовании // Педагогическая мастерская. Все для учителя. 2018. № 4 (76). С. 9-12.

17. Вербищкий Р.B. Социальные сети как мотивирующий помощник учителя // Английский язык в школе. 2018. № 1 (61). С. 45-49. 